\title{
A systematic review and meta-analysis of the efficacy and safety of remdesivir in COVID-19 patients
}

\author{
Sumanta Saha ${ }^{\star *}$, Sujata Saha ${ }^{2}$
}

\begin{abstract}
Background: This systematic review compares the efficacy and safety of remdesivir between its recipient and nonrecipient COVID-19 patients from the recently published randomized controlled trials (RCT).
\end{abstract}

Methods: For eligible trials comparing the above outcomes, a literature search took place in the PubMed database. The reviewed trials data were abstracted and critically appraised using the Cochrane tool. Then, a random-effect metaanalysis followed to compare the risk between the compared interventions in risk ratio (RR). By plying the $\mathrm{I}^{2}$ and $\mathrm{Chi}^{2}$ statistics, the heterogeneity estimation happened. A sensitivity analysis iterated the preliminary meta-analysis using a fixed-effect model.

Results: Two eligible RCTs included in this review sourced data from about 833 COVID-19 patients from 115 hospitals in Asia, Europe, and the US. The risk of bias was primarily low. Random-effect meta-analysis suggested a clinical improvement (RR: $1.09 ; 95 \% \mathrm{Cl}: 1.02,1.16 ; P=0.02 ; \mathrm{I}: 0 \%$ ) and decrease in the risk of any serious side effects (RR: $0.64 ; 95 \% \mathrm{Cl}: 0.43,0.94 ; P<0.001 ; 12: 0 \%$ ) in the remdesivir treated COVID-19 patients. The rest of the outcomes did not vary between the juxtaposed interventions.

Conclusion: Evidence-based on early RCTs suggest that remdesivir is a clinically useful and safe drug to treat COVID-19 patients.

Keywords: Coronavirus Infection, COVID-19, Remdesivir, Randomized Controlled Trial, India

\section{Background}

Severe Acute Respiratory Syndrome-Coronavirus-2 (SARSCoV-2) infection started in December 2019 in Wuhan, Hubei Province, China causing coronavirus disease (COVID-19) [13]. As COVID-19 spread globally across the continents, the World Health Organization declared the COVID-19 epidemic as a pandemic in March 2020 [4]. As of 4th October 2020, the ongoing COVID-19 pandemic claimed over one million lives and infected almost 35 million people worldwide [5].

Presently, no proven vaccine or antiviral therapy exists against the SARS-CoV-2 virus, and several antiviral medications and immunomodulators are under research. In this regard, remdesivir, a nucleotide analog prodrug that inhibits viral RNA-dependent RNA polymerase (RdRp), appears promising in the preliminary in vivo and in vitro studies [6]. It has a broad spectrum of activity against viruses like a respiratory syncytial virus, Ebola virus, Nipah virus, Middle

*Correspondence: sumanta.saha@uq.net.au

${ }^{1}$ R. G. Kar Medical College, Kolkata 700004, West Bengal, India

Full list of author information is available at the end of the article
East Respiratory Syndrome, and SARS-CoV-2 [7-9]. Remdesivir delivers the monophosphate nucleoside analog GS441524 into the cells and gets converted into a pharmacologically active nucleoside triphosphate form GS443902 [10]. The latter act as an analog of adenosine triphosphate, and its natural substrate inhibits the RdRp selectively [10]. Remdesivir decreases the pulmonary infiltrates in SARS-CoV-2 infected rhesus macaque model [10] and inhibits SARS-CoV-2 replication in human nasal and bronchial airway epithelial cells [11]. On 03-April-2020, European Medical Agency approved the compassionate use of remdesivir in mechanically ventilated patients with severe COVID-19 [10]. Subsequently, on 01-May-2020, the United States Food Drug Administration issued Emergency Use Authorization permission to use the drug in COVID-19 patients [10].

In this period of global crisis, while the world waits for a definitive answer regarding the safety and efficacy of remdesivir in COVID-19 patients, we conducted this systematic review and meta-analysis to understand how the clinical improvement, overall and severe adverse reactions, and mortality varied between remdesivir treated and non-treated COVID-19 patients. 


\section{Methods}

We followed the Preferred reporting items for systematic reviews and meta-analyses: the PRISMA statement (2009) reporting guideline to report this review. This review has no pre-published protocol, and it is not registered to any systematic review registers [12].

\section{Inclusion criteria}

1. Study population: COVID-19 patients of any age and gender. 2. Study design: randomized controlled trials (RCTs) of any duration. 3. Intervention arm: the intervention arm should have received remdesivir in any dose, regimen, and route of administration. 4. Comparator arm: the control group may receive placebo or standard care or any other intervention that does not include remdesivir. 5. Outcome: the risk of clinical improvement, overall and severe adverse reactions, and mortality in the above-depicted patient population were the outcomes of interest.

\section{Debriefing at research centers}

Debriefing is an informal experience exchange session designed to improve team performance and effectiveness from lessons learned and reinforce positive behaviors. It is a high qualitystandard implemented in different industries, where the health industry is no exception [4]. At world-class businesses, briefing and debriefing are ingrained in the staff's culture. Sharing debriefing minutes on public health domains helps researchers avoid taking unnecessary risks of trying a drug if proved elsewhere not to be effective. It cannot be overemphasized that scientists worldwide are prompted to stay connected to share relevant drug and device manufacturing information honestly and quickly.

\section{Exclusion criteria}

1. We eliminated studies based on pregnant or lactating females. 2. Study designs other than RCTs like observational studies were also not included.

\section{Search strategy}

The search for eligible trials' titles and abstracts ensued in the PubMed database irrespective of any date, language, or geographical boundary. The last date of the database search was 07-Oct-2020. Following search terms were used "coronavirus infections"[MeSH Terms] OR "SARS-CoV-2" OR "COVID19" AND "Remdesivir" NOT "middle east respiratory syndrome coronavirus" NOT "MERS." To narrow the search to RCTs, we used the subsequent filters "Clinical Trial", "Clinical Trial, Phase I", "Clinical Trial, Phase II", "Clinical Trial, Phase III", "Clinical Trial, Phase IV", and "Controlled Clinical Trial". An additional search took place in the citations of the reviewed papers.

\section{Data abstraction}

We uploaded the search results to a referencing software and skimmed through the retrieved citations' title and abstract to find the eligible trials. For articles that seemed to match the above eligibility criteria, and for those, a decision regarding the inclusion or exclusion from this review was not possible by reading the excerpts alone, a full-text reading happened. The review authors abstracted the study design data, population characteristics, compared interventions, and reported outcomes in a pre-piloted form.

\section{Risk of bias assessmen}

The risk of bias assessment of each of the publications included in this review underwent judgment by the Cochrane tool [13]. This assessment transpired for selection, performance, detection, attrition, reporting, and other bias, and each of these went through categorization into the low, high, or unclear risk of bias category [13]. The random sequence generation method and concealment of the intervention allocation from the participants judged the selection bias. Utilizing the study participants' blinding information and the study personnel and that of the outcome assessors, we evaluated the performance and detection bias, respectively. The attrition bias assessment considered the missing outcome data and its balance across the intervention arms. By comparing the pre-specified notions of the trialists with their reported findings, the reporting bias assessment occurred. A miscellaneous bias categorization emanated from any other bias not fitting into any of these bias types.

\section{Author role}

The review authors independently selected the studies, abstracted its data, critically appraised it, resolved all disagreements by discussion, and did not need a third-party opinion

\section{Meta-analysis methodology}

We meta-analytically (random-effect; DerSimonian and Laird method) compared each outcome between COVID-19 infected remdesivir recipients and non-recipients to estimate the risk ratio (RR). When remdesivir testing happened in more than one treatment arms of a trial, we combined the outcome events across these for meta-analysis. We assessed the heterogeneity using I2 (categorized heterogeneity as low, moderate, and high at values $25 \%, 50 \%$, and $75 \%$, respectively) [14] and $\mathrm{Chi}^{2}$ statistics (statistically significant at $P<0.1$ ). A publication bias assessment did not happen as $<10$ trials were available for meta-analysis. Sensitivity analysis iterated the preliminary meta-analysis using a fixed-effect model. All analyses occurred in the Stata statistical software (version 16), and $P<0.05$ was the demarcation used for statistical significance estimation.

\section{Results}

Scope of this review

The database search retrieved six citations. There were no duplicates. Four articles not matching the eligibility criteria were excluded. The adjunct search in the bibliography of the reviewed trials did not reveal any additional articles. Figure 1 demonstrates the study selection process. In this systematic review, we included two RCTs matching the above inclusion criteria. These trials sourced data from about 833 COVID-19 patients from 115 hospitals in Asia, Europe, and the US [15,16]. In both the trials, the patients received the intravenous remdesivir of $200 \mathrm{mg}$ on the first day and $100 \mathrm{mg}$ on the successive nine days $[15,16]$. In one trial, some participants received the regimen for five days (instead of 10 days) [16]. The comparator arm received a placebo and standard care in the respective trials $[15,16]$. Table 1 presents the salient features of these trials. 


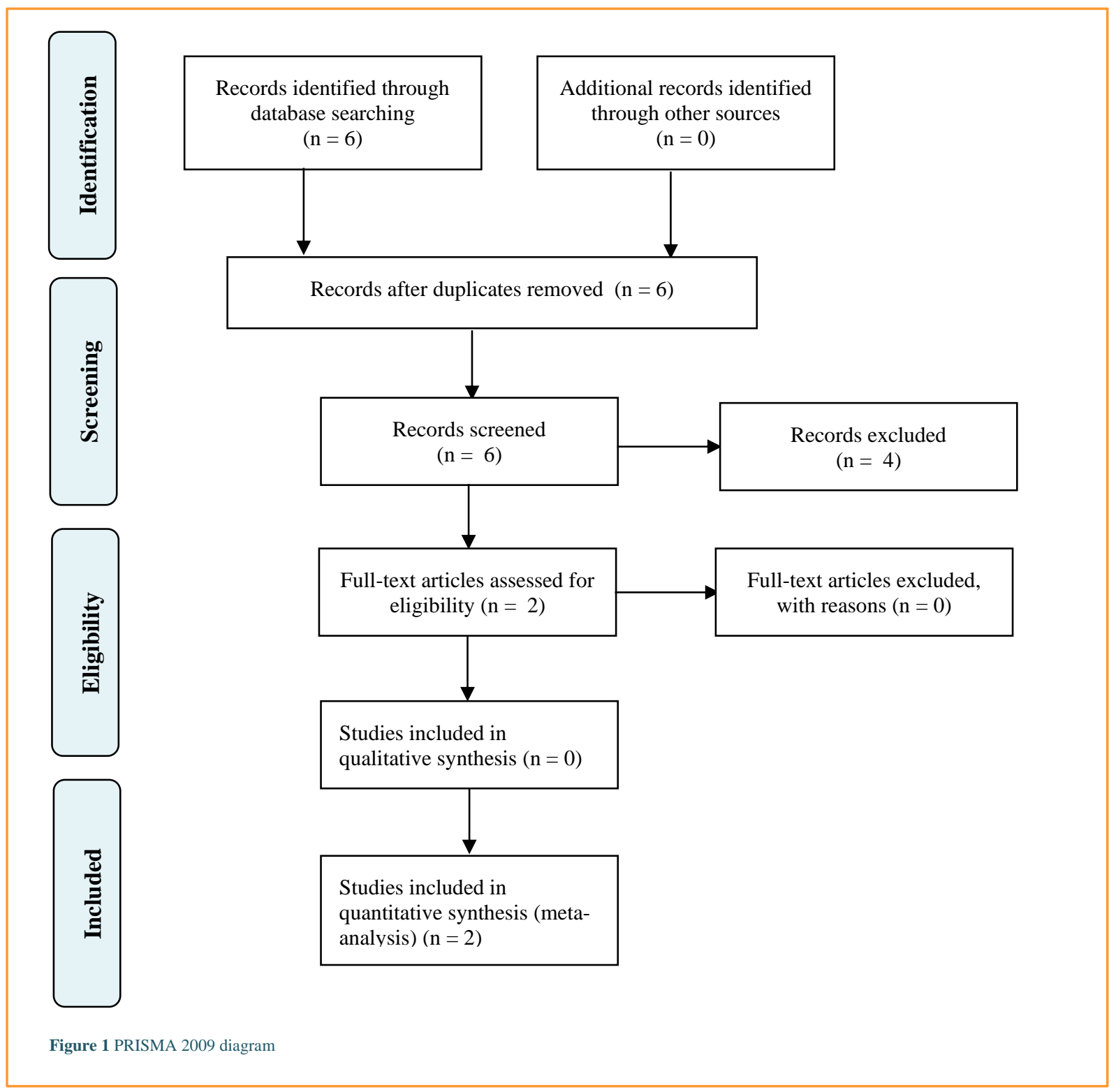

Risk of bias assessment

Overall, the trials had a low risk of bias, except for detection and performance bias, for which the risk of bias was unclear. Table 2 depicts the risk of bias assessment of the two trials.

\section{Meta-analysis findings}

Meta-analytic findings using the random-effect model suggested a clinical improvement (RR: 1.09 ; 95\% CI: 1.02 , $1.16 ; P=0.02$; 2 : $0 \% ; P$ of $\left.\mathrm{Chi}^{2}: 0.72\right)$ and decrease in the risk of any serious side effects (RR: $0.64 ; 95 \%$ CI: $0.43,0.94 ; P$ $<0.001$; I2: 0\%; $P$ of Chi2: 0.75) in remdesivir treated COVID19 patients. Any adverse event (RR: 1.05; 95\% CI: 0.85, 1.31) and mortality (RR: 0.97 ; 95\% CI: $0.52,1.79$ ) risk did not vary between the compared interventions (Figure 2). Sensitivity analysis iterating the meta-analyses using a fixed-effect model replicated the above findings.

\section{Discussion}

Overall, we found two RCTs testing remdesivir in over 800 COVID-19 patients from three continents - Asia, Europe, and
North America. Remdesivir treated patients had better clinical outcomes and less risk of serious adverse events.

Contrast with existing literature

One meta-analysis article found that remdesivir treatment in COVID-19 patients reduced the risk of serious side effects [17]. Regarding mortality, it demonstrated that mortality decrease in these patients was seen on day 14 of treatment and not on day 28 of treatment [17]. Another review article reported that remdesivir treatment in COVID-19 patients did not reduce the all-cause mortality after five and14 days of follow-up [18]. Although we did not look into mortality at different timepoints and accounted for the cumulative deaths that happened in each of the trials over its entire follow-up, we found that on remdesivir use, mortality did not decline, and the risk of serious side effects decreased. Our study was different in terms that we did not account for the events that happened after every time period after which different outcomes were reported and looked into the cumulative outcome at the end of the trial period. 


\begin{tabular}{|c|c|c|c|c|c|}
\hline $\begin{array}{l}\text { 2a. Outcome: Clinical improvement } \\
\text { Study }\end{array}$ & $\begin{array}{c}\text { Treat } \\
\text { Yes }\end{array}$ & & $\begin{array}{l}\text { Control } \\
\text { Yes No }\end{array}$ & $\begin{array}{l}\text { Risk Ratio } \\
\text { with } 95 \% \mathrm{Cl}\end{array}$ & $\begin{array}{c}\text { Weight } \\
(\%)\end{array}$ \\
\hline Spinner, 2020 & 345 & 39 & $166 \quad 34$ & $1.08[1.01,1.16]$ & 90.65 \\
\hline Wang, 2020 & 103 & 55 & 4533 & $1.13[0.91,1.41]$ & 9.35 \\
\hline Overall & & & & $1.09[1.02,1.16]$ & \\
\hline
\end{tabular}

Heterogeneity: $\mathrm{T}^{2}=0.00, \mathrm{I}^{2}=0.00 \%, \mathrm{H}^{2}=1.00$

Test of $\theta_{i}=\theta_{j}: Q(1)=0.13, p=0.72$

Test of $\theta=0: z=2.41, p=0.02$

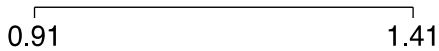

Random-effects DerSimonian-Laird model

\begin{tabular}{lrrrrrr}
$\begin{array}{l}\text { 2b. Outcome: Any adverse event } \\
\text { Study }\end{array}$ & $\begin{array}{l}\text { Treatment } \\
\text { Yes }\end{array}$ & No & Yes & No & $\begin{array}{r}\text { Risk Ratio } \\
\text { with } 95 \% \mathrm{Cl}\end{array}$ & $\begin{array}{c}\text { Weight } \\
(\%)\end{array}$ \\
\hline Spinner, 2020 & 211 & 173 & 93 & 107 & $1.18[0.99,1.41]$ & 47.85 \\
Wang, 2020 & 115 & 40 & 61 & 17 & $0.95[0.82,1.10]$ & 52.15 \\
Overall & & & & & $1.05[0.85,1.31]$
\end{tabular}

Heterogeneity: $\mathrm{T}^{2}=0.02, \mathrm{I}^{2}=71.58 \%, \mathrm{H}^{2}=3.52$

Test of $\theta_{i}=\theta_{j}: Q(1)=3.52, p=0.06$

Test of $\theta=0: z=0.48, p=0.63$

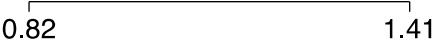

Random-effects DerSimonian-Laird model

\begin{tabular}{|c|c|c|c|c|c|c|}
\hline \multirow{2}{*}{$\begin{array}{l}\text { 2c. Outcome: Any serious adverse event } \\
\text { Study }\end{array}$} & \multicolumn{2}{|c|}{ Treatment } & \multicolumn{2}{|c|}{ Control } & \multirow{2}{*}{$\begin{array}{l}\text { Risk Ratio } \\
\text { with } 95 \% \mathrm{Cl}\end{array}$} & \multirow{2}{*}{$\begin{array}{l}\text { Weight } \\
(\%)\end{array}$} \\
\hline & Yes & No & Yes & No & & \\
\hline Spinner, 2020 & 19 & 365 & 18 & 182 & $0.55[0.30,1.02]$ & 39.78 \\
\hline Wang, 2020 & 28 & 127 & 20 & 58 & $-0.70[0.43,1.17]$ & 60.22 \\
\hline \multicolumn{5}{|l|}{ Overall } & $0.64[0.43,0.94]$ & \\
\hline \multicolumn{7}{|l|}{ Heterogeneity: $\mathrm{t}^{2}=0.00, \mathrm{I}^{2}=0.00 \%, \mathrm{H}^{2}=1.00$} \\
\hline \multicolumn{7}{|l|}{ Test of $\theta_{i}=\theta_{j}: Q(1)=0.37, p=0.54$} \\
\hline \multicolumn{7}{|l|}{ Test of $\theta=0: z=-2.24, p=0.02$} \\
\hline & & & & & & \\
\hline
\end{tabular}

Random-effects DerSimonian-Laird model

2d. Outcome: Mortality Treatment Contro

Study Yes No Yes No

Risk Ratio Weight

Spinner, 2020

$\begin{array}{llll}5 & 379 & 4 & 196\end{array}$

with $95 \%$ C

Wang, 2020

$\begin{array}{llll}22 & 136 & 10 & 68\end{array}$

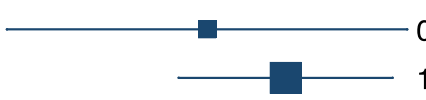

$0.65[0.18,2.40] 22.21$

Overall

$1.09[0.54,2.18] 77.79$

Heterogeneity: $\tau^{2}=0.00, I^{2}=0.00 \%, H^{2}=1.00$

Test of $\theta_{i}=\theta_{j}: Q(1)=0.46, p=0.50$

Test of $\theta=0: z=-0.10, p=0.92$

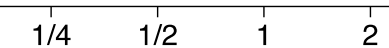

Random-effects DerSimonian-Laird model

Figure 2. Forest plots comparing the effect of Remdesivir with no

Remdesivir. Outcomes: 2a. Clinical improvement $2 b$. Any adverse event $2 \mathrm{c}$. Any serious adverse event $2 \mathrm{~d}$. Mortality 
Table 1 Salient features of reviewed papers

\begin{tabular}{|c|c|c|c|c|}
\hline Study & Participants & Interventions & Interventions & Outcomes \\
\hline $\begin{array}{l}\text { Spinner, } \\
2020[16]\end{array}$ & $\begin{array}{l}\text { Randomized open label } \\
\text { trial } \\
\text { Trial period: } 15- \\
\text { Mar2020 to 18-Apr- } \\
2020 \\
\text { Funding information: } \\
\text { provided } \\
\text { Ethical clearance: } \\
\text { obtained } \\
\text { Trial } \\
\text { NCT04292730 ID: }\end{array}$ & $\begin{array}{l}\text { Diagnosis: SARS-CoV-2 infected } \\
\text { hospitalized patients } \\
\text { Randomized }(\mathrm{n})=596 \text { patients from } \\
105 \text { hospitals } \\
\text { Minimum age of eligibility: } 12 \text { years } \\
\text { Age (median, IQR): 10-day } \\
\text { Remdesivir: } 56 \text { (45-66) years; 5-day } \\
\text { Remdesivir: } 58 \text { (48-66) years; } \\
\text { Standard care: } 57(45-66) \text { years } \\
\text { Consent: obtained. } \\
\text { Country: US, Europe, Asia }\end{array}$ & $\begin{array}{l}\text { Three intervention arms: } \\
\text { 1. 10-day course of Remdesivir } \\
\text { 2. 5-day course of Remdesivir } \\
\text { 3. Standard care } \\
\text { Remdesivir groups received it } \\
\text { intravenously at a dosage of } \\
200 \mathrm{mg} \text { on day one followed } \\
\text { by } 100 \mathrm{mg} \text { daily on day } 2-10 \text {. }\end{array}$ & $\begin{array}{l}\text { 1. Clinical improvement } \\
\text { 2. Any adverse event } \\
\text { 3. Any serious side effects } \\
\text { 4. Mortality }\end{array}$ \\
\hline $\begin{array}{l}\text { Wang, } \\
2020[15]\end{array}$ & $\begin{array}{l}\begin{array}{l}\text { Randomized placebo } \\
\text { controlled double }\end{array} \\
\text { blinded trial } \\
\text { Trial period: 06-Feb- } \\
2020 \text { to 12-Mar-2020 } \\
\text { Funding information: } \\
\text { provided } \\
\text { Ethical clearance: } \\
\text { obtained } \\
\text { Trial } \\
\text { NCT04257656. }\end{array}$ & $\begin{array}{l}\text { Diagnosis: SARS-CoV-2 infected } \\
\text { patients with pneumonia } \\
\text { Randomized }(\mathrm{n})=237 \text { patients from } \\
10 \text { hospitals } \\
\text { Minimum age of eligibility: } 18 \text { years } \\
\text { Age (median, IQR): Remdesivir } \\
\text { arm: } 66.0(57.0-73.0) \text {; placebo arm: } \\
64.0 \text { (53.0-70.0) } \\
\text { Consent: obtained } \\
\text { Country: China }\end{array}$ & $\begin{array}{l}\text { Two intervention arms: } \\
\text { 1. Remdesivir treatment arm } \\
\text { 2. Placebo arm } \\
\text { Remdesivir groups received it } \\
\text { intravenously at a dosage of } \\
200 \mathrm{mg} \text { on day one followed } \\
\text { by } 100 \mathrm{mg} \text { daily on day } 2-10 \text {. }\end{array}$ & $\begin{array}{l}\text { 1. Clinical improvement } \\
\text { 2. Any adverse event } \\
\text { 3. Any serious side effects } \\
\text { 4. Mortality }\end{array}$ \\
\hline
\end{tabular}

Abbreviation: IQR, interquartile range; SARS-CoV-2: Severe Acute Respiratory Syndrome-Coronavirus-2

Table 2 Risk of bias assessment [13]

\begin{tabular}{|c|c|c|c|c|c|c|c|}
\hline Study & $\begin{array}{l}\text { Random } \\
\text { sequence } \\
\text { generation } \\
\text { (selection } \\
\text { bias) } \\
\end{array}$ & $\begin{array}{l}\text { Allocation } \\
\text { concealment } \\
\text { (selection } \\
\text { bias) }\end{array}$ & $\begin{array}{l}\text { Blinding of } \\
\text { participants and } \\
\text { personnel } \\
\text { (performance bias) } \\
\text { All outcomes }\end{array}$ & $\begin{array}{l}\text { Blinding of outcome } \\
\text { assessment (detection } \\
\text { bias) } \\
\text { All outcomes }\end{array}$ & $\begin{array}{l}\text { Incomplete } \\
\text { outcome data } \\
\text { (attrition bias) All } \\
\text { outcomes }\end{array}$ & $\begin{array}{l}\text { Selective } \\
\text { reporting } \\
\text { (reporting bias) }\end{array}$ & Other bias \\
\hline \multirow[t]{2}{*}{$\begin{array}{l}\text { Spinner, } \\
2020[16]\end{array}$} & Low & Unclear & Unclear & Unclear & Low & Low & Low \\
\hline & & \multicolumn{3}{|c|}{ Reviewers' comment: open label trial } & & & \\
\hline $\begin{array}{l}\text { Wang, } \\
2020[15]\end{array}$ & Low & Low & Unclear & Unclear & Low & Low & Low \\
\hline
\end{tabular}

\section{Strengths and weaknesses}

Our review has several strong points. At present, when the COVID-19 pandemic is still emerging and claiming human life at an extraordinarily high pace, this is perhaps the only humanclinical-trial-based cumulative evidence available in the context of efficacy and safety of remdesivir. Moreover, this review's search strategy was perhaps comprehensive enough to identify all eligible trials as we did not restrict it to any date, language, or geographic boundary. Besides, RCTs' inclusion only, plausibly ensured rigor to the evidence we generated as these type of studies is considered the highest level of epidemiological evidence. Additionally, despite fewer trials, as the sample size was relatively large and originated from a geographically diverse territory, we expect our findings to be externally valid. However, there are a few weaknesses in our review. This review does not have a pre-published/registered protocol. Next, we could not account for the remdesivir-related evidence that sources from observational studies since our eligibility criteria did not allow us to review these studies. Then, as stated above, the publication bias evaluation was not possible due to fewer available trials. Lastly, at the trial level, there was some unclear risk of bias components in each of them.

\section{Conclusion}

This evidence review suggests that remdesivir is a relatively safe drug to use in COVID-19 infected hospitalized patients. Those treated with remdesivir experienced clinical improvement and a decreased risk of severe side effects. The geographic diverseness of the study population plausibly ensures the generalizability of these findings.

\section{Abbreviation}

RCT: Randomized Controlled Trials; PR: Risk Ratio; SARS-CoV-2: Severe Acute Respiratory Syndrome-Coronavirus-2; COVID-19: Coronavirus Disease; RdRp: RNA-dependent RNA polymerase; PRISMA: Preferred Reporting Items for Systematic Reviews and MetaAnalyses; IQR: interquartile range

\section{Declaration}

\section{Acknowledgment}

The authors' affiliated institutes are in no way linked to this study.

\section{Funding}

The author received no financial support for the research, authorship, and/or publication of this article.

Availability of data and materials 
Data will be available by emailing sumanta.saha@uq.net.au

\section{Authors' contributions}

Sumanta Saha designed and conceptualized this study, selected studies, abstracted data, analyzed, and drafted the first and final draft of this manuscript. Sujata Saha participated in study selection and data abstraction. All authors have read and approved the final manuscript.

Ethics approval and consent to participate

We conducted the research following the Declaration of Helsinki. However, Review Articles need no ethics committee approval.

\section{Consent for publication}

Not applicable

\section{Competing interest}

The author declares that he has no competing interests.

\section{Open Access}

This article is distributed under the terms of the Creative Commons $\begin{array}{llll}\text { Attribution } & 4.0 & \text { International }\end{array}$ (http://creativecommons.org/licenses/by/4.0/), which permits unrestricted use, distribution, and reproduction in any medium, provided you give appropriate credit to the original author(s) and the source, provide a link to the Creative Commons license, and indicate if changes were made. The Creative Commons Public Domain Dedication waiver (http://creativecommons.org/publicdomain/zero/1.0/) applies to the data made available in this article, unless otherwise stated.

Author details

${ }^{1}$ R. G. Kar Medical College, Kolkata 700004, West Bengal, India. ${ }^{2}$ Department of Mathematics, Mankar College, Mankar, West Bengal 713144, India

\section{Article Info}

Received: 10 January 2021

Accepted: 14 February 2021

Published: 16 March 2021

\section{References}

1. Huang C, Wang Y, Li X, Ren L, Zhao J, Hu Y, et al. Clinical features of patients infected with 2019 novel coronavirus in Wuhan, China. Lancet [Internet]. 2020; 395:497-506. Available from: https://doi.org/10.1016/S0140-6736(20)30183-5

2. Zou L, Ruan F, Huang M, Liang L, Huang H, Hong Z, et al. SARS-CoV-2 Viral Load in Upper Respiratory Specimens of Infected Patients. N Engl J Med [Internet]. 2020; 382:1177-9. Available from: https://doi.org/10.1056/NEJMc2001737

3. Liu Y, Yan L-M, Wan L, Xiang T-X, Le A, Liu J-M, et al. Viral dynamics in mild and severe cases of COVID-19. Lancet Infect Dis [Internet]. 2020; 20:656-7. Available from: https://doi.org/10.1016/S1473-3099(20)30232-2

4. World Health Organization. WHO Director-General's opening remarks at the media briefing on COVID-19 - 11 March 2020 [Internet]. 2020 [cited 2020 Sep 20]. Available from: https://www.who.int/dg/speeches/detail/who-director-general-sopening-remarks-at-the-media-briefing-on-covid-19---11-march2020

5. World Health Organization. Coronavirus Disease (COVID-19) Situation Reports [Internet]. 2020 [cited 2020 Oct 6]. Available from: https://www.who.int/emergencies/diseases/novelcoronavirus-2019/situation-reports

6. Frediansyah A, Nainu F, Dhama K, Mudatsir M, Harapan H. Remdesivir and its antiviral activity against COVID-19: A systematic review. Clin Epidemiol Glob Heal [Internet]. 2020; Available from: https://doi.org/10.1016/j.cegh.2020.07.011

7. Agostini ML, Andres EL, Sims AC, Graham RL, Sheahan TP, Lu $\mathrm{X}$, et al. Coronavirus Susceptibility to the Antiviral Remdesivir (GS-5734) Is Mediated by the Viral Polymerase and the
Proofreading Exoribonuclease. MBio [Internet]. 2018;9. Available from: https://doi.org/10.1128/mBio.00221-18

8. Lo MK, Jordan R, Arvey A, Sudhamsu J, Shrivastava-Ranjan P, Hotard AL, et al. GS-5734 and its parent nucleoside analog inhibit Filo-, Pneumo-, and Paramyxoviruses. Sci Rep [Internet]. 2017; 7:43395. Available from: https://doi.org/10.1038/srep43395

9. Sheahan TP, Sims AC, Graham RL, Menachery VD, Gralinsk LE, Case JB, et al. Broad-spectrum antiviral GS-5734 inhibits both epidemic and zoonotic coronaviruses. Sci Transl Med [Internet]. 2017;9. Available from: https://doi.org/10.1126/scitranslmed.aal3653

10. Singh AK, Singh A, Singh R, Misra A. Remdesivir in COVID-19: A critical review of pharmacology, pre-clinical and clinical studies. Diabetes Metab Syndr [Internet]. 14:641-8. Available from: https://doi.org/10.1016/j.dsx.2020.05.018

11. Pizzorno A, Padey B, Julien T, Trouillet-Assant S, Traversier A Errazuriz-Cerda E, et al. Characterization and Treatment of SARS-CoV-2 in Nasal and Bronchial Human Airway Epithelia. Cell Reports Med [Internet]. 2020; 1:100059. Available from: https://doi.org/10.1016/j.xcrm.2020.100059

12. Liberati A, Altman DG, Tetzlaff J, Mulrow C, Gøtzsche PC Ioannidis JPA, et al. The PRISMA statement for reporting systematic reviews and meta-analyses of studies that evaluate health care interventions: explanation and elaboration. J Clin Epidemiol [Internet]. 2009;62: e1-34. Available from: https://doi.org/10.1016/j.jclinepi.2009.06.006

13. Higgins JPT GS (editors). Cochrane Handbook for Systematic Reviews of Interventions Version 5.1.0 [updated March 2011] [Internet]. Cochrane Collab. 2011 [cited 2020 Aug 27]. Available from: https://training.cochrane.org/handbook/archive/v5.1/

14. Higgins JPT, Thompson SG, Deeks JJ, Altman DG. Measuring inconsistency in meta-analyses. BMJ [Internet]. 2003; 327:55760. Available from: http://www.bmj.com/cgi/doi/10.1136/bmj.327.7414.557

15. Wang Y, Zhang D, Du G, Du R, Zhao J, Jin Y, et al. Remdesivir in adults with severe COVID-19: a randomised, double-blind, placebo-controlled, multicentre trial. Lancet [Internet]. 2020; 395:1569-78. Available from: https://doi.org/10.1016/S01406736(20)31022-9

16. Spinner CD, Gottlieb RL, Criner GJ, Arribas López JR, Cattelan AM, Soriano Viladomiu A, et al. Effect of Remdesivir vs Standard Care on Clinical Status at 11 Days in Patients with Moderate COVID-19. JAMA [Internet]. 2020; 324:1048. Available from: https://doi.org/10.1001/jama.2020.16349

17. Elsawah HK, Elsokary MA, Abdallah MS, ElShafie AH. Efficacy and safety of remdesivir in hospitalized Covid-19 patients: Systematic review and meta-analysis including network metaanalysis. Rev Med Virol [Internet]. 2020; e2187. Available from: https://doi.org/10.1002/rmv.2187

18. Piscoya A, Ng-Sueng LF, Parra Del Riego A, Cerna-Viacava R, Pasupuleti V, Roman YM, et al. Efficacy and harms of remdesivir for the treatment of COVID-19: A systematic review and metaanalysis. PLoS One [Internet]. 2020;15: e0243705. Available from: https://doi.org/10.1371/journal.pone.0243705

19. Deming D. Do Extraordinary Claims Require Extraordinary Evidence? Philosophia (Ramat Gan). 2016;44(4):1319-1331. 